\title{
Effects of the Aqueous Leaf Extract Of Basella Alba on Sex Reversal of Nile Tilapia, Oreochromis Niloticus
}

\author{
Indranath Ghosal ${ }^{1}$, Suman Bhusan Chakraborty ${ }^{1}$ \\ ${ }^{1}$ Department of Zoology, University of Calcutta
}

\begin{abstract}
Three days old mixed sex juveniles of Nile tilapia (mean weight $0.025 \pm 0.009 \mathrm{~g}$; mean length $1.25 \pm$ $0.012 \mathrm{~cm}$ ) were treated by immersion method with aqueous leaf extract of Basella alba (ALEB) at the concentration of 0.0, 0.05, 0.10 and $0.15 \mathrm{~g} / \mathrm{l}$ for four weeks. The highest survival percentage (93.8 \pm 1.3$)$ was observed in $0.15 \mathrm{~g} / \mathrm{l}$ group, but there was no significant difference $(P>0.05)$ in survival percentage among the different treatment groups. The highest percentage of males (70.3 \pm 1.9$)$ was observed in $0.1 \mathrm{~g} / \mathrm{group}$ and it was significantly higher $(P<0.05)$ compared to all other treatment categories. Immersion treatment with ALEB caused significant increase $(P<0.05)$ in percentage of males compared to that in untreated control. The extract showed presence of phytochemicals such as tannins, saponins, steroids and alkaloids, which might be associated with its androgenic property.
\end{abstract}

Keywords: Aqueous extract, Basella alba, Orochromis niloticus, Phytochemicals, Sex reversal

\section{Introduction:}

The Nile tilapia, Oreochromis niloticus (Linnaeus) is a well-studied, fast-growing and widely cultured fish species that is currently ranked second only to carps in global production and is likely to be the most important cultured fish in the $21^{\text {st }}$ century[1]. Rapid growth rates, high tolerance to low water quality, efficient food conversion, resistance to disease, good consumer acceptance and ease of spawning make tilapia a suitable fish for culture[2]. Female organism of tilapine species have a high fecundity, generally reproducing at a small size and exhibiting stunted somatic growth at higher densities, while male tilapias exhibit faster growth rates and are often the preferred gender for monosex aquaculture[3]. Synthetic steroids are commonly used to induce sex reversal in tilapia but because of the potential hazards of such steroids; the use of new chemicals is a potential alternative to be explored[4]. Plant extracts containing diverse bioactive principles such as alkaloids, flavonoids, pigments, phenolics, terpenoids, steroids and essential oils and have been reported to promote various activities like antistress, growth promotion, appetite stimulation, tonic and immunostimulation, and antimicrobial properties in fish culture[5, 6]. Phytochemicals are also reported to block biosynthesis as well as action of estrogen by acting as aromatase inhibitors and antagonists to nuclear estrogen receptor in gonad germ cells[7] and hence may be considered as potential mean for inducing sex reversal in fish. However, there are significant variations regarding the efficacy of different phytochemicals for production of all-male fish population and the potential anabolizing and virilizing effects of such plant extracts needs to be clearly documented. Aqueous and methanol extracts from the dry leaves of Basella alba, a fast growing vegetable, probably originating from India[8], has been reported to possess active components that increase testosterone production in adult male rat testes during in vitro studies[9,10]. This edible plant has also been described to possess nutritional values including androgenecity in traditional medicines of several countries[11]. However, no studies have been reported related to its in vivo effect on sex reversal, growth and immunostimulation of fish. Considering these aspects, the objective of the present study was to investigate the potential effect of the aqueous leaf extract of $B$. alba (ALEB) on the masculinisation of $O$. niloticus by immersion technique.

\subsection{Collection of fish seed}

\section{Materials And Methods}

Just hatched juveniles of mixed-sex Nile tilapia was collected from the Fish Hatchery of West Bengal Government, oxygen packed and transported to the laboratory.

\subsection{Plant extracts preparations}

B. alba leaves were procured from the local plant market, washed in sterile distilled water, air-dried in shade and powdered. The aqueous leaf extract of $B$. alba (ALEB) was prepared by boiling $18 \mathrm{~g}$ powder in 1500 $\mathrm{ml}$ distilled water for 30 minutes and then filtering it with a Whatman filter paper twice[12]. The solution was prepared weekly.

\subsection{Immersion treatment of fish with plant extracts}

Three days old mixed sex juveniles of Nile tilapia (mean weight $0.025 \pm 0.009 \mathrm{~g}$; mean length $1.25 \pm$ $0.012 \mathrm{~cm}$ ) were randomly assigned in 24 glass aquaria to four different treatment groups (0.0 or control, 0.05 , 
0.1 and $0.15 \mathrm{~g} / \mathrm{l})$. The treatment was conducted for 30 days and the fish were exposed to the ALEB 4 times (once weekly) during this period. The aquaria were continuously aerated and maintained in heated $\left(\mathrm{T}=27 \pm 2^{0} \mathrm{C}\right.$ ) static systems. Water in all aquaria was replaced manually and the fish was kept under similar photoperiod (14 L: $10 \mathrm{D})$. Each aquarium was stocked with 40 fish. The fish was fed finely ground $(<500-1000 \mu \mathrm{m})$ artificial diet containing $30 \%$ crude protein (Tokyu, Japan) at a rate of $20 \%$ body weight / day. The experiment was conducted simultaneously in triplicate.

\subsection{Sexing of fish}

Sexing of the juvenile fish was done by the standard acetocarmine squash technique of gonads[13]. Histological studies of the gonads were also performed.

\subsection{Statistical analysis}

All data are expressed in terms of mean \pm standard error (SE). Treatment effects on different parameters were analyzed by one-way analysis of variance (ANOVA) after checking normality by ShapiroWilk's test. Where significant differences were found, a Tukey's test was performed for separating treatment means. All statistical analysis was performed using the SPSS version 11.5 for Windows.

\subsection{Qualitative phytochemical studies}

Qualitative phytochemical analysis of the ALEB was carried out using standard procedures[14,15,16].

\section{Results And Discussion}

Survival percentage in controls was similar to those observed in the ALEB treated groups, where no significant dose-related inter-group differences were noted $(\mathrm{P}>0.05)$ (Table 1). The highest survival percentage $(93.8 \pm 1.3)$ was observed in treatment with ALEB at the concentration of $0.15 \mathrm{~g} / \mathrm{l}$ while the lowest survival percentage was observed in treatment with ALEB at the concentration of $0.05 \mathrm{~g} / 1$ (83.75 \pm 8.75 ) (Table 1). The result indicates that immersion treatment with ALEB has no adverse effects on general fish health. All the treatment categories showed significantly higher $(\mathrm{P}<0.05)$ percentage of males compared to the control. The highest percentage of males $(70.3 \pm 1.9)$ was observed in treatment with ALEB at the concentration of $0.1 \mathrm{~g} / \mathrm{l}$, which is significantly higher $(\mathrm{P}<0.05)$ compared to all other groups (Table 1). Interestingly, all the treatment categories except the control group showed intersex with both male and female gonadal tissue. The highest percentage of intersex (12.4 \pm 4.3 ) was observed in ALEB $0.05 \mathrm{~g} / \mathrm{l}$ treatment group (Table 1). B. alba has been reported to be used in traditional medicine to treat sexual asthenia and infertility in man[17]. The methanol extract of its leaves was found to stimulate testosterone production in testicular fractions and Leydig cell cultures, and in normal adult albino male rats[10,18]. Similar increase in serum testosterone level was also reported in male rats treated with aqueous extract of $B$. alba through gastric intubation[9]. Although the present work indicates that immersion treatment with ALEB could induce high rate of masculinisation, whether this potency is caused by increase in androgen level cannot be deduced as the serum testosterone level was not measured during the study. Qualitative analysis for phytochemicals revealed the presence of tannins, saponins, steroids and alkaloids in ALEB, while flavonoids, glycosides and carbohydrates are not present in the extract (Table 2). These phytoconstituents might render the androgenic activity of the extract. Interestingly, the highest treatment concentration of $0.15 \mathrm{~g} / \mathrm{l}$ produced the lowest percentage of males among the different treatment categories (Table 1). Reduced masculinisation and paradoxical feminization has been observed in fish treated with high concentration of synthetic steroids as well $[19,20]$. A variety of pathways have been postulated to be associated with functional mechanisms of phyto-compounds causing both masculinisation and feminization at different concentrations [21]. The results emanating from this study indicates that ALEB might be used as an alternative method to produce all-male tilapia population in an environment-friendly manner using a natural product. However, the highest percentage of males produced by immersion in ALEB is $70 \%$, which is well below the ideal requirement of $100 \%$ male population. Thus, further studies would be required to establish an ideal treatment regime for production of all-male tilapia population using ALEB and to provide conclusive evidence regarding its efficacy to be used as a sex-reversal agent in tilapia culture.

Table 1: Percentage of survival, male, female and intersex during immersion treatment with ALEB at different concentrations. Different superscripts mark significant differences in means within columns.

\begin{tabular}{|l|l|l|l|l|}
\hline Treatment category & \% Survival & \% of male & \% of female & \% of intersex \\
\hline Control & $87.5 \pm 2.5^{\mathrm{a}}$ & $45.75 \pm 1.35^{\mathrm{a}}$ & $54.25 \pm 1.35^{\mathrm{b}}$ & $0.0 \pm 0.0^{\mathrm{a}}$ \\
\hline Basella $0.05 \mathrm{~g} / 1$ & $83.75 \pm 8.75^{\mathrm{a}}$ & $59.75 \pm 0.25^{\mathrm{b}}$ & $27.85 \pm 4.55^{\mathrm{a}}$ & $12.4 \pm 4.3^{\mathrm{a}}$ \\
\hline Basella $0.1 \mathrm{~g} / 1$ & $84.6 \pm 5.4^{\mathrm{a}}$ & $70.3 \pm 1.9^{\mathrm{c}}$ & $21.55 \pm 2.15^{\mathrm{a}}$ & $8.15 \pm 0.25^{\mathrm{a}}$ \\
\hline Basella $0.15 \mathrm{~g} / 1$ & $93.8 \pm 1.3^{\mathrm{a}}$ & $55.35 \pm 1.45^{\mathrm{b}}$ & $34.15 \pm 1.75^{\mathrm{a}}$ & $10.5 \pm 0.3^{\mathrm{a}}$ \\
\hline
\end{tabular}


Table 2: Preliminary phytochemical screening of aqueous extract of B. alba leaves. '+' = present, '- '= absent.

\begin{tabular}{|c|c|}
\hline PHYTOCHEMICAL & Basella alba aqueous extract \\
\hline Tannin & + \\
\hline Saponin & - \\
\hline Flavonoid & + \\
\hline Steroid & + \\
\hline Alkaloid & - \\
\hline Carbohydrate & - \\
\hline Glycoside & \\
\hline
\end{tabular}

\section{Acknowledgement}

The research is financed by the University Grants Commission (Major Research Project, F. No. 42519/2013(SR)). The Vice Chancellor, University of Calcutta is also acknowledged for giving permission for conducting the research work.

\section{References}

[1]. M.T Ridha, Comparative study of growth performance of three strains of Nile tilapia, Oreochromis niloticus, L. at two stocking densities. Aquacult Res, 37, 2006, 172-179.

[2]. D.M.S.D El-Saidy \& M.M.A Gaber . Effect of dietary protein levels and feeding rates on growth performance, production traits and body composition of Nile tilapia, Oreochromis niloticus (L.) cultured in concrete tanks. Aquaculture Research, 36, $2005,163-171$.

[3]. G.A Hines \& S.A Watts. Nonsteroidal chemical sex manipulation of tilapia. Journal of the World Aquaculture Society, 26, 1995, 98-102.

[4]. D.M Papoulias, D.B Noltie \& Tillitt D.E. Effects of methyl ᄀtestosterone exposure on sexual differentiation in medaka, Oryzias latipes. Marine Environmental Research, 50, 2000, 181-184.

[5]. T. Citarasu. Herbal biomedicines: a new opportunity for aquaculture industry. Aquacult. Int., 18, 2010, 403-414.

[6]. S.B. Chakraborty, C. Hancz, Application of phytochemicals as immunostimulant, antipathogenic and antistress agents in finfish culture. Rev. Aquaculture. 3, 2011, 103-119.

[7]. M.A. Rempel, D. Schlenk, Effects of environmental estrogens and antiandrogens on endocrine function, gene regulation, and health in fish. Int. Rev. Cell Mol. Biol., 267, 2008, 207-252.

[8]. O. Bamidele, A.M. Akinnuga, J.O. Olorunfemi, O.A. Odetola, C.K. Oparaji \& N. Ezeigbo. Effects of aqueous extract of Basella alba leaves on haematological and biochemical parameters in albino rats. Afr J Biotechnol, 9, 2010, 6952-6955.

[9]. P.F. Moundipa, P. Kamtchouing, N. Koueta, J. Tantchou, N.P.R Foyang \& F.T. Mbiapo, Effects of aqueous extracts of Hibiscus macranthus and Basella alba in mature rat testis function. Journal of Ethnopharmacology, 65, 1999. 133-139.

[10]. P.F. Moundipa, N.S.E. Beboy, F. Zelefack, S. Ngoula, E. Tsamo, W-B. Schill, \& T.K. Monsees, Effects of Basella alba and Hibiscus macranthus extracts on testosterone production of adult rat and bull Leydig cells. Asian J. Androl., 7, 2005, $411-417$.

[11]. N. Siriwatanametanon, B.L. Fiebich, T. Efferth, J.M Prietoa \& M. Heinrich. Traditionally used Thai medicinal plants: In vitro antiinflammatory, anticancer and antioxidant activities. J Ethnopharmacol, 130, 2010, 196-207.

[12]. Ş. Çek, F. Turan \& E. Atik. The effects of gokshura, Tribulus terrestris on sex differentiation of guppy, Poecilia reticulata. Pakistan Journal of Biological Sciences, 10, 2007, 718-725.

[13]. R.D. Guerrero \& W.L. Shelton. An aceto-carmine squash method for sexing juvenile fishes. Prog. Fish-Cult, 36, $1974,56$.

[14]. M.O. Malpani, P.R. Rajput, V.D, Mane \& P.S. Dhabe, Phytochemical screening, anifungal activity and curative impact on Channa punctatus fish of Butea monosperma (Lam): flower, leaves and gum. Der Pharmacia Lettre, 3, 2011, 271-280.

[15]. A. Kumar \& A. Bhardwaj, Comparative, qualitative and quantitative chemotypic characterization among north Indian Tribulus terrestris. International Research Journal of Pharmacy, 3, 2012, 212-218.

[16]. S. Ray, S. Chatterjee \& C.S. Chakrabarti, Antiprolifertive activity of allelochemicals present in aqueous extract of Synedrella nodiflora (L.) Gaertn. in apical meristems and Wistar rat bone marrow cells. IOSR Journal of Pharmacy, 3, 2013, 1-10.

[17]. R. Adhikari, H.N. Naveen Kumar \& S.D. Shruthi. A Review on Medicinal Importance of Basella alba L. Int. J. Pharma. Sci. Drug Res. 4, 2012, 110-114.

[18]. E.A. Nantia, C. Travert, F-P.T. Manfo, S. Carreau, T.K. Monsees, P.F. Moundipa, Effects of the Methanol Extract of Basella alba L (Basellaceae) on Steroid Production in Leydig Cells. Int J Mol Sci., 12, 2011, 376-384.

[19]. J.A. Beardmore, G.C. Mair, R.I. Lewis, Monosex male production in finfish as exemplified by tilapia: applications, problems, and prospects. Aquaculture, 197, 2001, 283-301.

[20]. R.H. Devlin, Y. Nagahama, Sex determination and sex differentiation in fish: an overview of genetic, physiological, and environmental influences. Aquaculture, 208, 2002, 191-364.

[21]. S.B. Chakraborty, P. Horn \& C. Hancz, Application of phytochemicals as growth-promoters and endocrine modulators in fish culture. Rev Aquaculture, 2013, DOI: 10.1111/raq.12021. 